\title{
Classification of Indramayu's Mangoes Based on Shape Features Using Neural Network and Rule Based Programming
}

\author{
Sumarudin*, Iryanto, Eka Ismantohadi \\ Informatics Department, Politeknik Negeri Indramayu \\ Jl. Lohbener Lama No. 8, Lohbener-Indramayu, Indonesia. \\ *Email: ashumarudin@gmail.com
}

\begin{abstract}
Sumarudin, Iryanto, Ismantohadi E. 2017. Classification of Indramayu's Mangoes Based on Shape Features Using Neural Network and Rule Based Programming. Proc Internat Conf Sci Engin 1: 245-248. Object classification using image processing simplifies the process. Many approaches have been used to classify the object. In general, classification of mangoes uses image of leaves. In this research, we do a slightly different approach using image of mango itself. Here, two kinds of method are used to classify the object. Implementations of deep learning using neural network and rule based programming are used in the process. Comparative study of the methods are presented in the article. Our result show that accuracy of deep learning approach is better than the rule based programming. The accuracy is $80 \%$ and $8 \%$ for neural network and rule based programming, respectively.
\end{abstract}

Keywords: Deep learning, neural network, rule based programming, classification of mango

\section{INTRODUCTION}

Object classification using image processing has become one of interesting fields so that many researchers focus their research in the field in recent years. The image processing simplifies the process. Many approaches have been used to classify the object including deep learning for instances see (Krizheysky et al., 2012), (Vedaldi and Lenc, 2015), and (Vedaldi et al). In the other hand, the process uses image of leaves as described in (Agustin and Prasetyo, 2011), and (Riska et al., 2015). Some methods that used in the process are convolutional neural network (Krizheysky et. al., 2012), (Vedaldi and Lenc, 2015), and (Vedaldi et al), Fourier descriptor, probabilistic neural network (Kadir et al., 2013), fuzzy neural network (Whidhiasih et al., 2012), general regression neural network (Zulkifli, 2009), and rule based programming (Taufiq, 2010).

Several previous researches on the field will be introduced. In the work of (Kadir, 2015), it is described that Fourier descriptor method had $88 \%$ accuracy. His other work (Kadir and Prasetyo, 2011), showed a better accuracy. It is $93.75 \%$ accuracy using the probabilistic neural network. In the work of (Whidhiasih et al., 2012), study comparative of fuzzy neural network and neural network. The methods were used to identify maturity of local and import mangosteen fruit. For the local fruit, the fuzzy method has better accuracy than the neural network method 89\%:75\%. But different result was shown for the import fruit, the neural network has $100 \%$ accuracy. Same accuracy is also shown using general regression neural network. As for the ruled based programming, in the work of (Taufiq, 2010), it is explained that the method showed good result in identifying papilionaceae.

In this research, we use slightly different approach. Here, we use image of mango itself in the identification process. From the literature study as elaborated before, the deep learning method based on neural network shows promising result. Therefore, here we implement neural network and we compare its result with result of rule based programming. The comparison will be presented next.

\section{MATERIALS AND METHODS}

\section{Image of Mangoes}

In this research, some images of mangoes are needed. Three kinds of mangoes are chosen namely cengkir, gajah, and gedong (see Figure 1-3). The images are taken using DLSR camera.

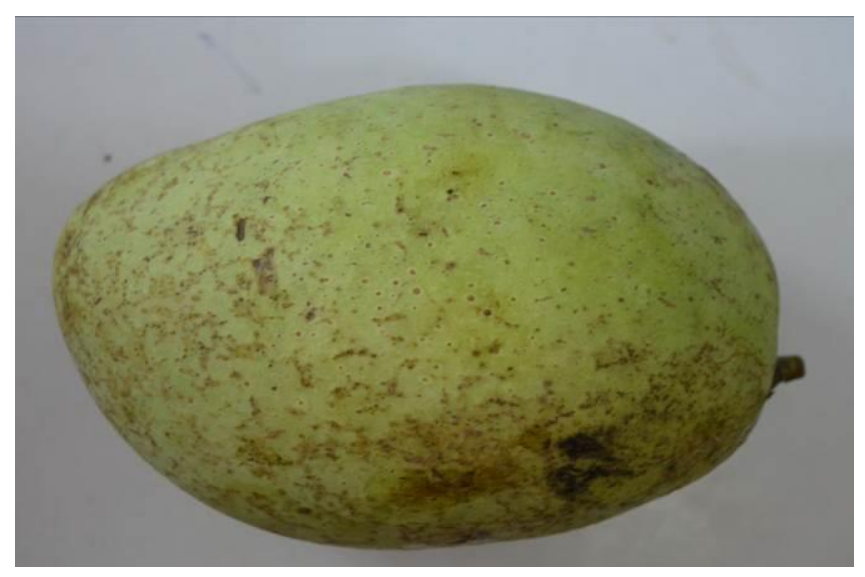

Figure 1. Image of cengkir mango. 


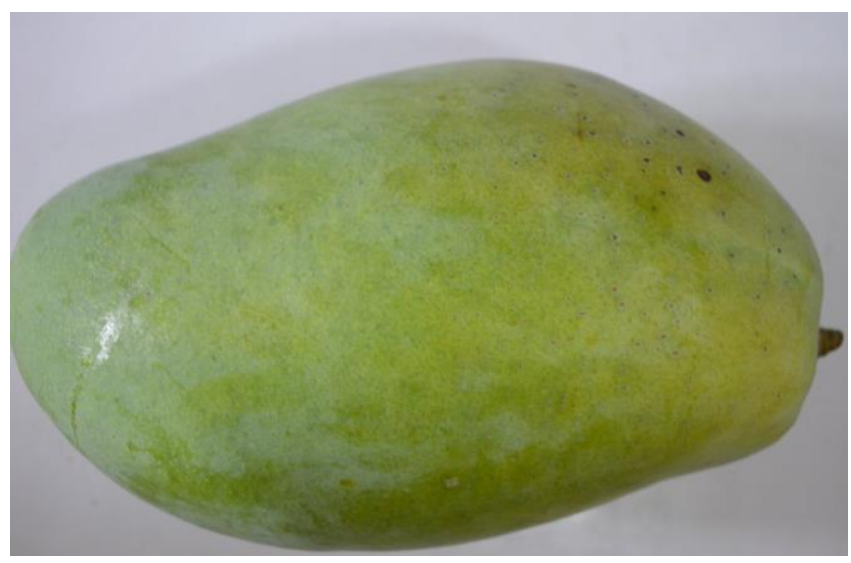

Figure 2. Image of gajah mango.

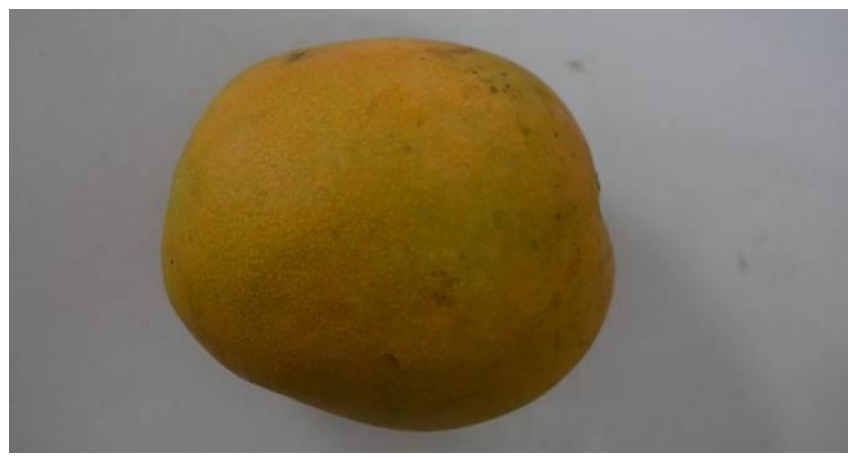

\section{Extraction of Shape Features}

Extraction of shape features of image of mango is done to get several information. Here the information is aspect ratio (AR) and roundness (R). According to (Kadir, 2015) and (Kadir et al., 2013), the features can be written as follows:

$A R=\frac{\text { width of fruit }}{\text { Iength of } f \text { ruit }}$

$\mathrm{R}=\frac{4 \pi A}{p^{2}}$

Where A describes area of the fruit image and $\mathrm{p}$ is perimeter.

\section{Neural Network}

A Neural Network (NN) can be defined as a function $f$ mapping data $\mathbf{x}$, to an output $\mathbf{y}$ (Vedaldi et al.). Here, the data are image whereas the output vector is the label of the kinds of mangoes. The function $f$ is a simple function usually called as layer. The layer in simplest case can be arranged into sequence. But in difficult cases, it may lead to complex interconnection as for illustration see Figure 1. The figure describes computation layer/block of function $f$ in neural network with neuron input $x$ and weight $w$ and output $y$.

Figure 3. Image of gedong mango.

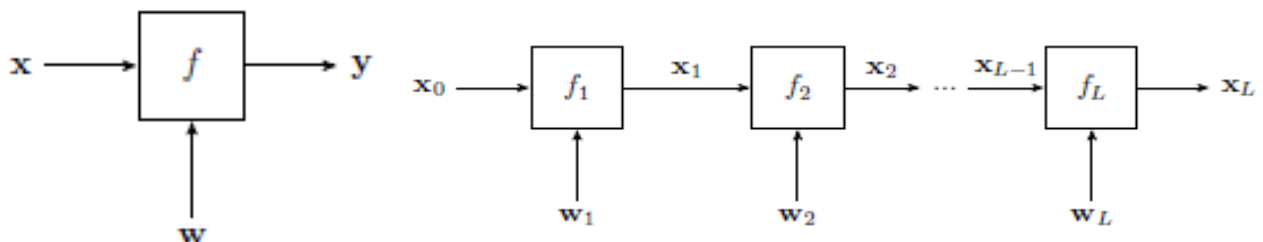

Figure 4. Computation block/layer (left) and simple structure of layer function $f$ (right)

Here we use neural network tool box in matlab see (Demuth et al., 2008).

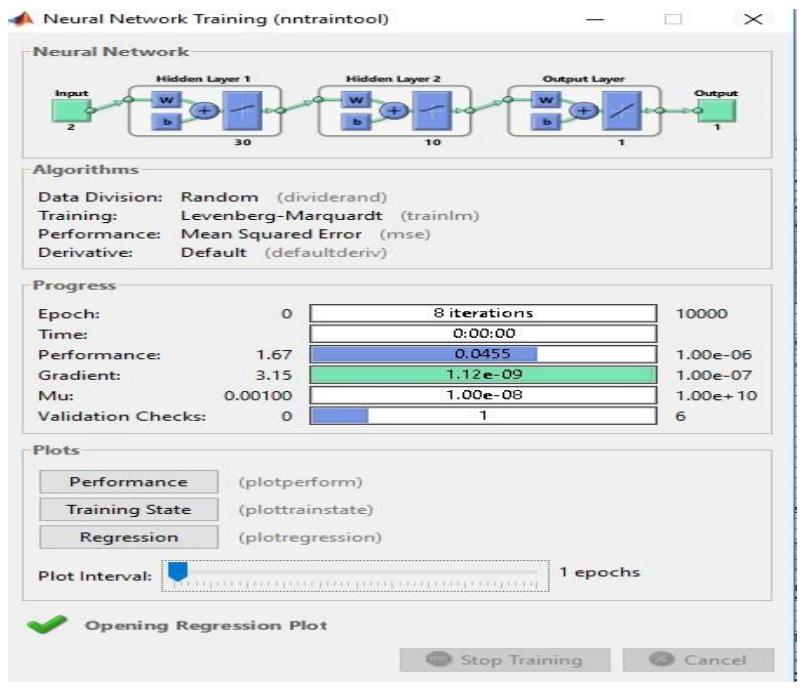

Figure 5. Neural network training tool in matlab.

\section{Rule Based Programming}

Here we need the shape features of each label of mangoes. Range of the features of each label can be seen in Table 1 as follows.

Table 1. Range of shape features of mangoes.

\begin{tabular}{llll}
\hline $\begin{array}{l}\text { Shape } \\
\text { Features }\end{array}$ & Cengkir & Gajah & Gedong \\
\hline $\begin{array}{l}\text { Aspect ratio } \\
\text { (AR) }\end{array}$ & $0.8394-0.9022$ & $0.8058-0.8209$ & $0.7630-0.7893$ \\
Roundness (R) & $0.5879-0.6507$ & $0.5110-0.7021$ & $0.4839-0.6086$ \\
\hline
\end{tabular}

Classification using the method is done by comparing shape features of mangoes taken using measurement to shape features of image of mangoes. Result of the classification depends on the label of the comparison result. If the features of image of mangoes do not match with data in the Table 1 , we set as unknown. 
Thus the classification process can be written in the following procedure:

1. Read image of mango.

2. Set label as unknown.

\section{Classification Scheme}

Process of the classification can be written as follows.
3. Calculate shape features of the input image.

4. Decide the label using result in the second step.

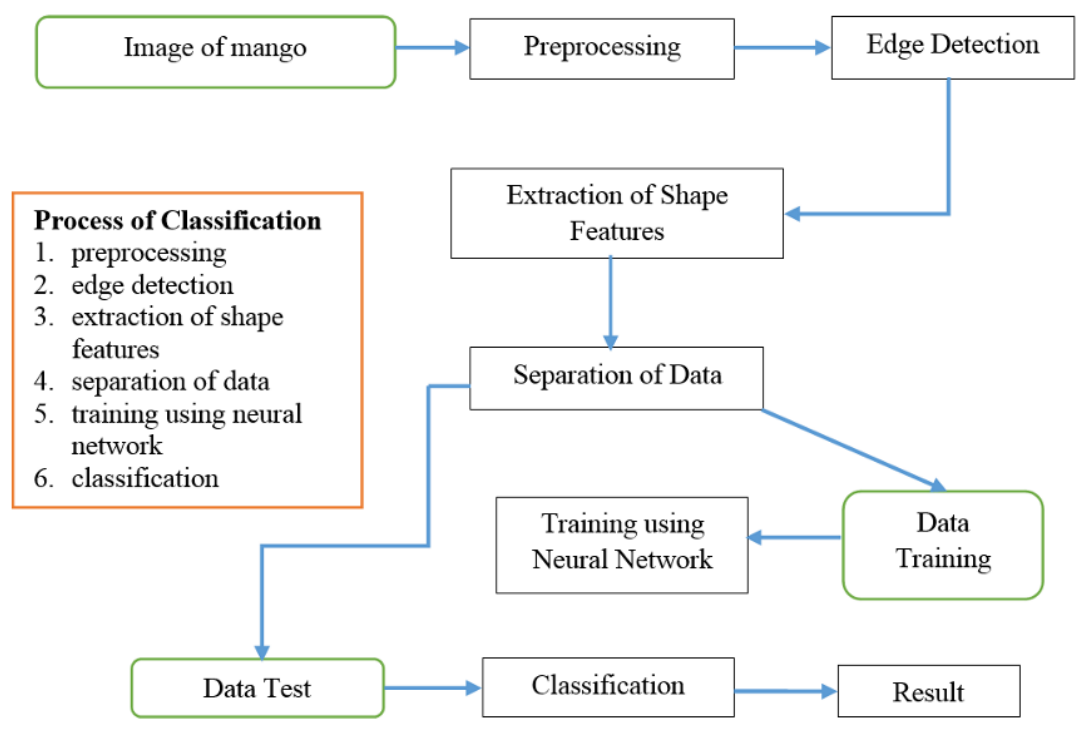

1. Preprocessing: the first process e.g resizing image, image enhancement

2. Edge detection: it is using Canny edge detection and tresholding as image segmentation.

3. Extraction of shape features: Calculating aspect ratio and roundness.

4. Segmentation of data: The taken data are separated into to types namely data training and data test. Each type consists of three labels. Label 1 is for cengkir, label 2 is for gajah, and label 3 is for gedong.

5. Training using neural network approach: the training is for the data training with the given label. In this research the process is done using matlab neural network tool box (NNTool).

6. Classification: the classification process is done for the data test one by one. Here, the classification uses two methods namely neural network and rule based programming. Result of the process is validated using the real label to measure its accuracy.

\section{RESULTS AND DISCUSSION}

The following result of classification done using 15 data training with 5 data for each labels. Whereas the data testing are 11 data. Screenshot of one of results can be seen in Figure 4. In the figure, we use image of gajah mango. It is shown in the figure that result of neural network method get same result whereas the rule based programming does not.

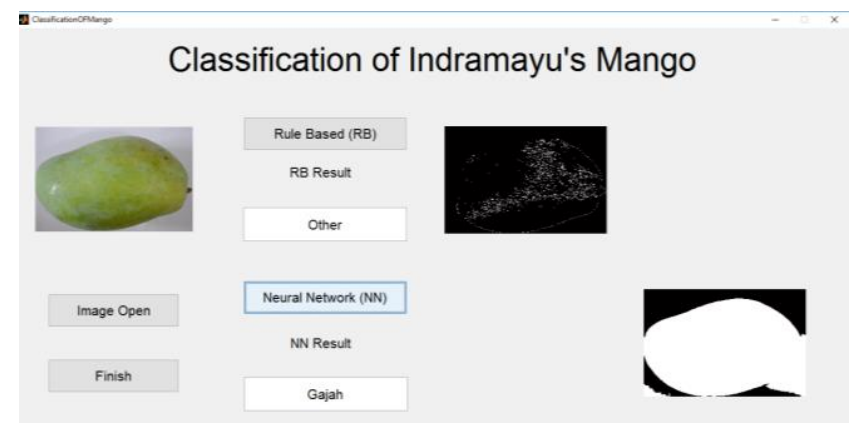

Figure 6. Result of classification

\section{Discussion}

In general, the neural network method has good enough result but the rule based programming does not. Accuracy for the neural network method is $86.67 \%$. Ways in taking data may lead to the result. Especially for the rule based programming since the method use the shape features of images directly. Therefore, measurement of the features becomes crucially. In our data, several mangoes have almost similar properties that lead to wrong label. Improvement of the accuracy will be our future goal.

\section{ACKNOWLEDGEMENTS}

The work of authors are supported by Politeknik Negeri Indramayu. 


\section{REFERENCES}

Agustin, S., \& Prasetyo, E. 2011. Klasifikasi jenis pohon mangga gadung dan curut berdasarkan tesktur daun. SESINDO 2011Jurusan Sistem Informasi ITS, 58-64.

Kadir, A. 2015. Leaf identification using Fourier descriptors and other shape features. Gate to Computer Vision and Pattern Recognition, 1(1), 3-7.

Kadir, A., Nugroho, L. E., Susanto, A., \& Santosa, P. I. 2013. Leaf classification using shape, color, and texture features. arXiv preprint arXiv:1401.4447.

Krizhevsky, A., Sutskever, I., \& Hinton, G. E. 2012. Imagenet classification with deep convolutional neural networks. In Advances in neural information processing systems (pp. 1097-1105).

Riska, S. Y., Cahyani, L., \& Rosadi, M. I. 2015. Klasifikasi Jenis Tanaman Mangga Gadung dan Mangga Madu Berdasarkan Tulang Daun. Jurnal Buana Informatika, 6(1).
Vedaldi, A., \& Lenc, K. 2015. Matconvnet: Convolutional neural networks for matlab. In Proceedings of the 23rd ACM international conference on Multimedia (pp. 689-692). ACM.

Vedaldi, A., Lenc, K., \& Gupta, A. Convolutional Neural Networks for MATLAB. Chicago.

Whidhiasih, R. N., Guritman, S., \& Suprio, P. T. 2012. Klasifikasi Kematangan Buah Manggis Ekspor dan Lokal Berdasarkan Warna dan Tekstur Menggunakan Fuzzy Neural Network. Jurnal Ilmu Komputer dan Agri-Informatika, 1(2).

Zulkifli, Z. 2009. Plant leaf identification using moment invariants \& general regression neural network (Doctoral dissertation, Universiti Teknologi Malaysia).

Taufiq. 2010. Identifikasi tumbuhan kacang-kacangan (Papilionaceae) menggunakan sistem pakar dengan pendekatan forward chaining (Skripsi, Universitas Islam Negeri Syarif Hidayatullah).

Demuth, H., Beale, M., \& Hagan, M. 2008. Neural network toolbox ${ }^{\mathrm{TM}}$ 6. User's guide, 37-55.

Dreyfus, G. 2005. Neural networks: methodology and applications. Springer Science \& Business Media. 